\section{Work-related Physical Trauma and Fibromyalgia}

\section{To the Editor:}

I have been a medical consultant to the Workplace Safety and Insurance Board Appeals Tribunal (WSIAT) of Ontario, Canada, for many years. I was therefore particularly interested to read the article by Fitzcharles, et $a l^{1}$. I congratulate the authors for gathering and presenting these data. Regrettably, the Discussion section of their report contains statements that are confusing and may generate more heat than light.

The authors seem to be taken aback that WSIAT relied heavily in its decisions on the opinions of rheumatology consultants. In 2009, in an editorial in The Journal, Shir and Fitzcharles proposed that family physicians be considered the most appropriate and best qualified to manage fibromyalgia $(\mathrm{FM})^{2}$. They held up as an example the data by Shleyfer, et $a l$, who showed that rheumatologists agreed with a diagnosis of FM made by family physicians in $71 \%$ of cases $^{3}$. I personally agree that it is desirable for family physicians to take primary responsibility for the care of patients with FM. In Canada this is more easily said than done. In a recent survey, $76 \%$ of general practitioners (GP) described the care of patients with FM as time-consuming and frustrating, $36 \%$ had doubts about their ability to diagnose FM, and $23 \%$ thought that patients with FM were malingerers ${ }^{4}$. It is usual for courts, tribunals, and arbitrators dealing with medical issues to call in experts. Given the figures cited above on GP attitudes, there appears to be justification for WSIAT to have acted as it did. I am perplexed to read that the authors find the WSIAT reliance on expert opinion "disturbing," and that they go on to state that "assigning considerable weight to both diagnosis and attribution of cause to the specialist is therefore contrary to recommended medical practice" 1 .

The authors then criticize the use of tender points in diagnosing FM. Their report reviews the period 2006-2011. Until 2010, the criteria for FM that were widely accepted in North America were the classification criteria of the American College of Rheumatology $(\mathrm{ACR})^{5}$. These criteria include the presence of $\geq 11$ tender points. It was not until May 2010 that the ACR preliminary diagnostic criteria were published; these require a certain number of positive responses to a questionnaire, but not the elicitation of any physical signs ${ }^{6}$. The authors' criticism of the use of tender points is confusing. How else were WSIAT consultants to diagnose FM before May 2010? We read that "tender point examination is...controversial and open to bias and has been discarded as diagnostic criteria [sic] in an individual patient...". In other words, the ACR classification criteria are invalid. Since when?

Dr. Fitzcharles was a coauthor of the report on the preliminary ACR criteria ${ }^{6}$. It states: "the preliminary criteria are not meant to replace the ACR classification criteria." We also read in the same paper that "ACR classification criteria performed well in specialty clinics" 6 .

One reason for the introduction of the preliminary criteria was to avoid the difficulty many physicians, especially those in primary care, had in examining for tender points ${ }^{6,7}$. Most rheumatologists had no such problems. The 2 sets of criteria largely overlap in the clinical diagnosis 6 .

Fitzcharles, et al then fire a last salvo at the tender points. We are told that "tender point examination can be faked"1. So it can, but I suspect that it is a tad more difficult to do so than giving false answers on the preliminary diagnostic criteria questionnaire.

The question of whether work-related physical trauma can cause FM has been and will likely continue to be debated in the foreseeable future until appropriate studies are done ${ }^{8}$. Unfortunately, patients applying for compensation will likely continue to be suspected of exaggerating their symptoms, if not of downright malingering.

MANFRED HARTH, MD, FRCPC, Emeritus Professor of Medicine, Western University, Central AIM Clinic, 458 Central Avenue, London, Ontario N6B 2E5, Canada. Address correspondence to Dr. Harth; E-mail: mharthc593@rogers.com

\section{REFERENCES}

1. Fitzcharles MA, Ste-Marie PA, Shir Y. A medicolegal analysis of workplace appeals for fibromyalgia as a compensable condition following workplace soft-tissue injury. J Rheumatol 2013;40:323-8.

2. Shir Y, Fitzcharles MA. Should rheumatologists retain ownership of fibromyalgia? J Rheumatol 2009;36:667-70.

3. Shleyfer E, Jotkowitz A, Karmon A, Nevzorov R, Cohen H, Buskila D. Accuracy of the diagnosis of fibromyalgia by family physicians: Is the pendulum shifting? J Rheumatol 2009;36:170-3.

4. Hayes SM, Myhal GC, Thornton JF, Camerlain M, Jamison C, Cytryn KN, et al. Fibromyalgia and the therapeutic relationship: Where uncertainty meets attitude. Pain Res Manag 2010;15:385-91.

5. Wolfe F, Smythe HA, Yunus MB, Bennett RM, Bombardier C, Goldenberg DL, et al. The American College of Rheumatology 1990 criteria for the classification of fibromyalgia. Report of the Multicenter Criteria Committee. Arthritis Rheum 1990;33:160-72.

6. Wolfe F, Clauw DJ, Fitzcharles MA, Goldenberg DL, Katz RS, Mease P, et al. The American College of Rheumatology preliminary diagnostic criteria for fibromyalgia and measurement of symptom severity. Arthritis Care Res 2010;62:600-10.

7. Harth M, Nielson WR. The fibromyalgia tender points: Use them or lose them? A brief review of the controversy. J Rheumatol 2007;34:914-22.

8. White KP, Carette S, Harth M, Teasell RW. Trauma and fibromyalgia: Is there an association and what does it mean? Semin Arthritis Rheum 2000;29:200-16.

J Rheumatol 2013;40:9; doi:10.3899/jrheum.130306 